\title{
Sensitivity and Specificity of Anterior Cruciate Clinical Examination in Acute Setting Before and After Hemarthrosis Aspiration
}

\author{
Görkem Kıyak ${ }^{1}$ and Motasım K Bawaneh ${ }^{2 *}$ and Tevfik Balikçi ${ }^{3}$ \\ ${ }^{1}$ Department of Orthopaedic Surgery, Academic Hospital, Turkey \\ ${ }^{2}$ Department of Orthopaedic Surgery, Ataşehir Avicenna Hospital, Turkey \\ ${ }^{3}$ Department of Orthopaedic Surgery, Medistate Hospital, Turkey
}

Submission: July 19, 2018; Published: August 20, 2018

*Corresponding author: Motasım K Bawaneh, Department of Orthopaedic Surgery, Atașehir Avicenna Hospital, kayıșdağı cad. No. 47 Atașehir İstanbul, Turkey, Tel: +905337106833; Email: drbawaneh.ort@gmail.com

\begin{abstract}
Objectives: To define the accuracy of the clinical test for assessing anterior cruciate ligament (ACL) tears on the acute setting before and after hemarthrosis aspiration.

Background: ACL is among the most commonly injured ligament of the knee in sports injuries.The most frequently used physical examinations to diagnose an ACL injury are the Lachman test, anterior drawer test, and pivot shift test. After acute complete ACL injury patients present to clinics with hemarthrosis in the knee joint. It was hypothesized that sensitivity and specificity of Lachman test, anterior drawer test, and pivot shift test increases after hemarthrosis aspiration.
\end{abstract}

Methods: 62 patients consulted due to twisting knee injury with hemarthrosis were enrolled in the study. Patients were examined by an emergency physician and a senior orthopedic consultant. All three tests were performed before and after hemarthrosis aspiration and sensitivity, and specificity of tests was recorded after MRI imaging. VAS scores for pain before and after aspiration were recorded.

Results: Hemarthrosis aspiration significantly reduced visual analog scale (VAS) scores $(\mathrm{P}<0.0001)$. Aspiration improved sensitivity of all three diagnostic tests but did not affect specificity Lachman test has best diagnostic accuracy to detect ACL rupture in acute conditions

Conclusion: In suspected ACL injury it is recommended to perform diagnostic tests after hemarthrosis aspiration.

Keywords: Lachman; Pivot shift; Anterior drawer; Hemarthrosis

\section{Introduction}

Complete ACL rupture is a frequent sports trauma. Three commonly applied physical examinations to diagnose ACL injury are Lachman test, anterior drawer test and pivot shift test $[1,2]$. Meta-analysis of previous studies showed that these tests have variable sensitivity and specificity especially in acute injuries $[3,4]$. Unreliable and inaccurate clinical examination makes clinician uncertain of the diagnosis and compel to make unnecessary, expensive MRI imaging or misdiagnose an ACL tear.

A study by Perera et al. [5] stated that there has been at best only minor improvement in the diagnostic rate and delays, certainly of acute ACL injury, since a study in 1996. The overall clinical diagnostic rate remains disconcertingly low as does the delay to consulting a soft-tissue knee specialist $[5,6]$. Patients with acute ACL injury from sports trauma always have some amount of hemarthrosis. Hemarthrosis tensions the joint capsule more as knee flexion increases and the patient becomes more uncomfortable. Three classic diagnostic tests to diagnose an ACL injury forces knee to flexion or performed in flexion. Even in some circumstances, patients do not allow the clinician to do these tests because of pain.

We evaluated the effect of hemarthrosis aspiration on the sensitivity and specificity of Lachman, pivot shift and anterior drawer tests in acute ACL tears.

\section{Materials and Methods}

62 patients who referred to emergency service with twisting knee trauma enrolled in the study. All patients in the study later referred to radiology for MRI imaging to confirm diagnosis.After patients full conset was recieved they were first examined by an emergency physician and Lachman, pivot shift and anterior drawer tests were performed and then consulted to orthopedic surgeon as suspected ACL injury. After orthopedic consultant examination, hemarthrosis aspirated and with patient permission Lachman, pivot shift and anterior 
drawer tests were repeated by both emergency physician and orthopedic consultant. VAS scores for pain before and after aspiration were recorded.Patients were asked to choose which diagnostic test was most painful and uncomfortable before and after aspiration. Data were collected for later evaluation. For the anterior drawer test, the patient's knee is flexed to 90 degrees, and the hip is flexed to 45 degrees. The patient's foot is held on the table by the examiner's body with the examiner sitting on the patient's forefoot and the foot in neutral rotation. The examiner's hands are placed around the tibia to ensure that the hamstring muscles are relaxed. The tibia is then drawn forward on the femur. The normal amount of movement that should be present is approximately $6 \mathrm{~mm}$ according to the International Knee Documentation Committee (IKDC 2000) [7].

The pivot shift test is performed with the patient supine. Hip is flexed at 20 to 30 degrees, knee is extended while maintaining a valgus stress at the knee and in some cases an anterior force on the fibula head and the proximal aspect of tibia while flexing knee and in first 10 to 20 degrees of flexion the tibia will sublux posteriorly caused by the iliotibial tract indicates a positive pivot shift test [8]. The IKDC 2000 knee examination form grades the pivot shift test as equal, glide (+), clunk (++), or gross (+++) [7].

The Lachman test is performed with the patient lying supine and with the involved extremity on the side of the examiner. The examiner holds the patient's knee between full extension and 30 degrees of flexion. The patient's femur is stabilized with one of the examiner's hands while the proximal aspect of the tibia is moved forward with the other hand. Increased anterior tibial translation with a soft end point more than $5 \mathrm{~mm}$ compared to the other side constitutes a positive test, indicating disruption of the ACL. As described by the IKDC 2000 [7].

\section{Results}

38 of 62 patients diagnosed with ACL rupture after MRI imaging. Specificity of tests before and after hemarthrosis aspiration did not differ. The sensitivity of tests improved after hemarthrosis aspiration both for emergency physician and ortho consultant (Tables 1 \& 2). Paired t-test showed a significant decrease in VAS score after aspiration of hemarthrosis $(\mathrm{P}<$ 0.0001) (Table 3).

Table 1: Sensivity and specifity of diagnostic tests before and after aspiraton.

\begin{tabular}{|c|c|c|c|c|c|c|c|c|c|}
\hline $\begin{array}{c}\text { Emergency } \\
\text { Physician }\end{array}$ & & TP & FP & FN & TN & $\begin{array}{c}\text { Sensivity [95 \% CI] } \\
\text { before Aspiration }\end{array}$ & $\begin{array}{c}\text { Specifity [95 \% CI] } \\
\text { before Aspiration }\end{array}$ & $\begin{array}{c}\text { Sensivity [95 \% CI] } \\
\text { after Aspiration }\end{array}$ & $\begin{array}{c}\text { Specifity [95 \% CI] } \\
\text { after Aspiration }\end{array}$ \\
\hline $\begin{array}{c}\text { Lachman } \\
\text { Test }\end{array}$ & Before & 14 & 4 & 24 & 20 & 0.36 & 0.83 & 0.44 & 0.81 \\
\cline { 2 - 10 } & After & 17 & 2 & 21 & 22 & {$[0.22,0.54]$} & {$[0.61,0.94]$} & {$[0.2,0.61]$} & {$[0.7,0.98]$} \\
\hline $\begin{array}{c}\text { Pivot shift } \\
\text { Test }\end{array}$ & Before & 8 & 2 & 30 & 22 & 0.21 & 0.91 & 0.31 & 0.91 \\
\cline { 2 - 10 } & After & 12 & 2 & 26 & 22 & {$[0.10,0.37]$} & {$[0.71,0.98]$} & $0.1,0.48]$ & {$[0.7,0.98]$} \\
\hline $\begin{array}{c}\text { Anterior } \\
\text { drawer } \\
\text { Test }\end{array}$ & Before & 10 & 6 & 28 & 18 & 0.26 & 0.75 & 0.36 & 0.83 \\
\cline { 2 - 9 } & After & 14 & 4 & 24 & 20 & {$[0.13,0.43]$} & {$[0.52,0.89]$} & {$[0.2,0.54]$} & {$[0.6,0.94]$} \\
\hline
\end{tabular}

TP: True Positive; FP: False Positive; FN: alse Negative; TN: True Negative; Cl: Confidence Interval.

Table 2: Sensivity and specifity of diagnostic tests before and aspiraton.

\begin{tabular}{|c|c|c|c|c|c|c|c|c|c|}
\hline $\begin{array}{c}\text { Ortho } \\
\text { Consultant }\end{array}$ & & TP & FP & FN & TN & $\begin{array}{c}\text { Sensivity [95 \% CI] } \\
\text { before aspiration }\end{array}$ & $\begin{array}{c}\text { Specifity [95 \% CI] } \\
\text { before aspiration }\end{array}$ & $\begin{array}{c}\text { Sensivity [95 \% CI] } \\
\text { after aspiration }\end{array}$ & $\begin{array}{c}\text { Specifity [95 \% CI] } \\
\text { after aspiration }\end{array}$ \\
\hline $\begin{array}{c}\text { Lachman } \\
\text { Test }\end{array}$ & Before & 22 & 1 & 16 & 23 & 0.57 & 0.95 & 0.68 & 0.91 \\
\cline { 2 - 10 } & After & 26 & 2 & 12 & 22 & {$[0.40,0.73]$} & {$[0.76,0.99]$} & {$[0.5,0.81]$} & {$[0.7,0.98]$} \\
\hline $\begin{array}{c}\text { Pivot shift } \\
\text { Test }\end{array}$ & Before & 16 & 1 & 22 & 23 & 0.42 & 0.95 & 0.55 & 0.91 \\
\cline { 2 - 10 } & After & 21 & 2 & 17 & 22 & {$[0.26,0.59]$} & {$[0.76,0.99]$} & {$[0.3,0.71]$} & {$[0.7,0.98]$} \\
\hline $\begin{array}{c}\text { Anterior } \\
\text { drawer } \\
\text { Test }\end{array}$ & Before & 12 & 4 & 26 & 20 & 0.31 & 0.83 & 0.47 & 0.87 \\
\cline { 2 - 9 } & After & 18 & 3 & 20 & 21 & {$[0.18,0.48]$} & {$[0.61,0.94]$} & {$[0.3,0.63]$} & {$[0.66,0.96]$} \\
\hline
\end{tabular}

TP: True Positive; FP: False Positive; FN: False Negative; TN: True Negative; Cl: Confidence Interval.

Patients selected anterior drawer test as the most discomforting test before hemarthrosis aspiration. Among 62 patients 8 selected Lachman test (12.9\%), 22 selected pivot shift test (35.4\%) and 32 selected anterior drawer test (51.6\%). Patients selected pivot shift test as most discomforting test after hemarthrosis aspiration. Among 62 patients 6 selected Lachman test (9.6\%), 42 selected pivot shift test (67.7\%) and 32 selected anterior drawer test $(22.5 \%)$.

\section{Discussion}

Our study showed that Lachman test has the best diagnostic accuracy to detect ACL rupture in acute conditions. The test is performed between 20 to 30 degrees of flexion, so it is less painful than anterior drawer test. Also, no valgus stress is applied like pivot shift test which can cause pain when ligamentous injury present. Moreover, the secondary restraints do not contribute much to stability in this test position [9]. Disadvantage of the 
test is, it is hard to perform appropriately to male patients with high body mass index due to large thigh girth.

Table 3: Vas scores before and after Aspiration.

\begin{tabular}{|c|c|c|}
\hline Parameter & VAS score before & VAS score after \\
\hline Mean & 8.11 & 5.98 \\
\hline Std deviation & 1.34 & 1.18 \\
\hline Minimum & 6 & 3 \\
\hline Maximum & 93 & 35 \\
\hline Median & 8 & 6 \\
\hline Lower 95 \% CI & 7.83 & 5.56 \\
\hline Upper 95 \% CI & 8.52 & 6.28 \\
\hline
\end{tabular}

Cl: Confidence Interval.

Pivot shift test is a complicated maneuver, and there is a learning curve to perform this test properly. Studies showed that sensitivity of this test might increase with experience [10]. Also, this test needs to be performed to an MCL intact knee. An MCL deficient knee may produce false negative results for this test. Our experience showed that orthopedic residents could perform this test more efficiently after several trials on anesthetized patients. This study also showed us that patients are very uncomfortable when they feel the tibial subluxation posteriorly and begin to resist this maneuver. In our study, the sensitivity of this test was extremely low when it is performed by emergency physicians.

Anterior drawer test is known to show low sensitivity in an acute setting. There is three noted possible low sensitivity for this test. First hemarthrosis that prevents knee flexion to 90 degrees. Second, resistant muscle action of the hamstrings secondary to joint pain produces a vector force opposite to the anterior translation of the tibia. Third, the posterior horn of the medial meniscus becomes buttressed against the posterior margin of the medial femoral condyle and may prevent anterior translation of the tibia [11]. Present study also showed that aspiration of hemarthrosis increases the sensitivity of anterior drawer test on the acute setting. Patients selected anterior drawer test as most painful and discomforting before hemarthrosis aspiration and pivot shift test after aspiration. Aspiration decreased VAS score and improve knee flexion.

\section{Conclusion}

Hemarthrosis aspiration improved the sensitivity of all three tests both for orthopedic consultants and emergency physicians but did not affect specificity. Aspiration of knee joint significantly reduced pain and VAS scores in patients and allowed doctors to perform diagnostic tests more accurately. Lachman test has the best diagnostic accuracy to detect ACL rupture in acute conditions. In suspected ACL injury it is recommended to perform diagnostic tests after hemarthrosis aspiration.

\section{References}

1. Sandber R, Balkfors B, Henricson A, Westlin N (1986) Stability tests in knee ligament injuries. Arch Orthop Trauma Surg 106(1): 5-7.

2. Slocum DB, James SL, Larson LR, Singer KM (1976) Clinical tests for anterolateral rotary instability of knee. Clin Orthop Relat Res 118: 6369.

3. Benjaminse A, Gokeler A, van der Schans CP (2006) Clinical Diagnosis of Anterior Cruciate Ligament Rupture: A Meta Analysis, Journal of Orthopaedic and Sports Physical Therapy. J Orthop Sports Phys Ther 36(5): 267-88.

4. Van Eck CF, van den Bekerom MPJ, Fu FH, Poolman RW (2013) Methods to diagnose acute anterior cruciate ligament rupture: a meta analysis of physical examinations with and without anesthesia. Knne Surg Sports Traumatol Arthrosc 21(18): 1895-1903.

5. Perera NS, Joel J, Bunola JA (2013) Anterior cruciate ligament rupture: Delay to diagnosis. Injury, Int. J. Care Injured 44(12): 1862-1865.

6. Bollen SR, Scott BW (1996) Rupture of the anterior cruciate ligament a quiet epidemic Injury 27(6): 407-409.

7. International Knee Documentation Committee (2000) IKDC Knee Examination Forms 19: 16-17.

8. Galway RD, Beaupre A, MacIntosh DL (1980) Pivot shift: a clinical sign of symptomatic anterior cruciate insufficiency. J Bone Joint Surg Br 54: 763-764.

9. Müller W (1983) Das Knie. Form, Funktion und ligamentare Widerherstellungschirurgie. Berlin, Springer Verlag, Germany.

10. Solomon DH, Simel DL, Bates DW, Katz JN, Schaffer JL (2001) The rational clinical examination. Does this patient have a torn meniscus or ligament of the knee? Value of the physical examination. JAMA 286(13): 1610-1620.

11. Torg JS, Conrad W, Kalen V (1976) Clinical diagnosis of anterior cruciate ligament instability in the athlete. Am J Sports Med 4(2): 84-93.
Your next submission with Juniper Publishers will reach you the below assets

- Quality Editorial service

- Swift Peer Review

- Reprints availability

- E-prints Service

- Manuscript Podcast for convenient understanding

- Global attainment for your research

- Manuscript accessibility in different formats

( Pdf, E-pub, Full Text, Audio)

- Unceasing customer service

Track the below URL for one-step submission

https://juniperpublishers.com/online-submission.php 